\title{
RUBRIEKEN
}

REVIEW ESSAY

\section{Publiek-private samenwerking in Nederland en Vlaanderen: een review van veertien proefschriften $^{*}$}

\author{
Marlies Hueskes, Joop Koppenjan \& Stefan Verweij
}

\begin{abstract}
De recente golf van promotieonderzoeken naar publiek-private samenwerking (PPS) roept de vraag op naar de staat van de huidige PPS-praktijk in Nederland en Vlaanderen en het onderzoek daarnaar. Onze review laat zien dat de proefschriften voornamelijk infrastructurele projecten onderzoeken die met langlopende $\operatorname{DBFM}(\mathrm{O})$-contracten worden gerealiseerd. De proefschriften groeperen zich rond vraagstukken betreffende effectiviteit, transactiekosten en legitimiteit. Een rode draad door hun bevindingen heen is dat of en hoe PPS werkt, sterk contextafhankelijk is. Veel van de aanbevelingen benadrukken het belang van de zachte aspecten van samenwerking. De nadruk ligt op de vroege projectfasen: voorbereiding, aanbesteding en contractering. Daarnaast laat de generaliseerbaarheid van de studies te wensen over. Er is meer onderzoek nodig naar de latere projectfasen van PPS alsook meer programmatisch, kwantitatief en (internationaal) vergelijkend PPSonderzoek.
\end{abstract}

\section{Inleiding}

Publiek-private samenwerking (PPS) staat in Nederland en Vlaanderen vol in de aandacht bij politici en beleidsmakers (zie bijv. Loxham \& Ducatteeuw, 2015; Rijkswaterstaat, 2011; Rutte \& Samsom, 2012). PPS wordt gezien als een wenselijk sturingsmodel voor het organiseren van publieke diensten en het oplossen van complexe maatschappelijke vraagstukken. In de literatuur worden vele vormen en definities onderscheiden (Klijn, 2010; Linder, 1999; Schaeffer \& Love-

* Dit onderzoek is medegefinancierd met een doctoraatsbeurs van strategisch onderzoek door het Agentschap voor Innovatie door Wetenschap en Technologie (IWT). Daarnaast is deze review mede tot stand gekomen in de context van het onderzoeksproject Governance for Smartening Public Private Partnerships (NWO-projectnummer 409-14-014), dat gefinancierd wordt door NWO, NSOB, Deltares, RebelGroup, ResetManagement, Twynstra Gudde en Rijkswaterstaat. Dr. S. Verweij is werkzaam als postdoctoraal onderzoeker aan de Rijksuniversiteit Groningen bij de Basiseenheid Planologie, s.verweij@rug.nl. M. Hueskes, MSc is promovenda aan de Universiteit Antwerpen bij het Departement Politieke Wetenschappen, marlies.hueskes@uantwerpen.be. Prof. dr. J.F.M. Koppenjan is hoogleraar Bestuurskunde aan de Erasmus Universiteit Rotterdam bij de Afdeling Bestuurskunde, koppenjan@fsw.eur.nl. 
ridge, 2002; Weihe, 2008), maar vaak gaat het om publieke projecten die met langlopende Design-Build-Finance-Maintain-Operate-contracten (DBFMO-contracten) worden gerealiseerd (Klijn, 2009). Soms gaat het ook om allianties, waarbij partnerschap centraal staat.

De toenemende populariteit van PPS lijkt gepaard te gaan met een versterkte roep om kritische reflectie op de praktijk en prestaties ervan (zie recentelijk bijv. Bakker, 2015; Verhees, Van Marrewijk, Leendertse, \& Arts, 2015). De meerwaarde van PPS is namelijk in potentie groot, maar deze wordt lang niet altijd gerealiseerd. Zo komt publiek-private samenwerking soms moeilijk van de grond (Koppenjan, 2005), vallen de prestaties tijdens de uitvoering of na de oplevering tegen of ontstaan er conflicten. Zo resulteerden de bouw van de Tweede Coentunnel en de aanleg van de A15 Maasvlakte-Vaanplein (zie Verbraeken \& Weissink, 2014) in plaats van in samenwerking in vechtprojecten.

Hoewel publiek-private samenwerking geen nieuw fenomeen is (Grimsey \& Lewis, 2004; Klijn, 2009), lijkt er de laatste jaren sprake te zijn van een golf aan studies naar PPS in Nederland en Vlaanderen. Dit riep bij ons de vraag op wat deze golf biedt aan inzichten over zowel de praktijk als het onderzoek naar PPS. In dit artikel presenteren wij een review van veertien recente proefschriften naar PPS in Nederland en Vlaanderen, verschenen in de periode 2012-2015. Een overzicht van de veertien onderzochte studies is te vinden in tabel 1.

Vanuit wetenschappelijk oogpunt is het interessant om na te gaan wat deze proefschriften aan wetenschappelijk gefundeerde kennis over PPS hebben opgeleverd, maar ook hoe tot nu toe dit verschijnsel is bestudeerd: wat zijn hun theoretische en methodologische bijdragen? Met onze review willen wij een bijdrage leveren aan de vertaling van wetenschappelijk PPS-onderzoek naar de praktijk van publiek-private samenwerking. Wij gaan concreet in op de volgende aspecten:

- Wat verklaart de recente golf van PPS-proefschriften?

- Hoe wordt PPS benaderd in de proefschriften: hoe wordt het gedefinieerd en op welke sectoren ligt de focus?

- Wat zijn de belangrijkste en opvallendste verschillen tussen de proefschriften wat betreft de onderwerpkeuze, de theoretische en disciplinaire oriëntatie en de methodologie?

- Wat zijn de belangrijkste en opvallendste bevindingen van de proefschriften?

- Wat zijn de belangrijkste en opvallendste aanbevelingen die worden gedaan richting de praktijk van PPS?

\section{Werkwijze}

Naar aanleiding van onze constatering dat er de afgelopen jaren veel PPS-proefschriften zijn verschenen, hebben wij in de database van NARCIS gezocht naar Nederlandse proefschriften op het gebied van PPS. Deze initiële lijst is vervolgens aangevuld met Vlaamse en Nederlandse PPS-proefschriften die wij via navraag en online zoekacties hebben geïdentificeerd. Er is gebruikgemaakt van de zoektermen "Public-Private Partnership", "Publiek-Private Samenwerking" en de afkortingen hiervan. Het gaat in deze review dus om proefschriften die zich expliciet heb- 
Tabel 1 Overzicht van de proefschriften

\begin{tabular}{|c|c|c|c|}
\hline $\begin{array}{l}\text { Promotie- } \\
\text { jaar }\end{array}$ & Auteur & Universiteit & $\begin{array}{l}\text { Korte omschrijving onderzoeks- } \\
\text { onderwerp }\end{array}$ \\
\hline 2012 & Hoezen & $\begin{array}{l}\text { Universiteit } \\
\text { Twente }\end{array}$ & $\begin{array}{l}\text { Publiek-private onderhandelingen en verbinte- } \\
\text { nissen in de concurrentiegerichte dialoog }\end{array}$ \\
\hline 2012 & Lousberg & $\begin{array}{l}\text { Technische Uni- } \\
\text { versiteit Delft }\end{array}$ & $\begin{array}{l}\text { Interventies bij disfunctionele conflicten in } \\
\text { publiek-private samenwerking }\end{array}$ \\
\hline 2013 & Eversdijk & $\begin{array}{l}\text { Universiteit Maas- } \\
\text { tricht }\end{array}$ & $\begin{array}{l}\text { Overwegingen van politici en besluitvormers } \\
\text { om te kiezen voor publiek-private samenwer- } \\
\text { king }\end{array}$ \\
\hline 2013 & Lenferink & $\begin{array}{l}\text { Rijksuniversiteit } \\
\text { Groningen }\end{array}$ & $\begin{array}{l}\text { Private betrokkenheid bij de integratie van de } \\
\text { verschillende fasen uit het infrastructuurplan- } \\
\text { proces }\end{array}$ \\
\hline 2013 & Sanders & $\begin{array}{l}\text { Universiteit } \\
\text { Twente }\end{array}$ & $\begin{array}{l}\text { Legitimiteit van beleids- en besluitvorming in } \\
\text { publiek-private samenwerking bij groengaspro- } \\
\text { jecten }\end{array}$ \\
\hline 2013 & Verhees & $\begin{array}{l}\text { Rijksuniversiteit } \\
\text { Groningen }\end{array}$ & $\begin{array}{l}\text { Adaptieve planning van publiek-private samen- } \\
\text { werking }\end{array}$ \\
\hline 2014 & De Schepper & $\begin{array}{l}\text { Vrije Universiteit } \\
\text { Brussel }\end{array}$ & $\begin{array}{l}\text { Succesfactoren voor publiek-private samen- } \\
\text { werking en de rol van stakeholdermanagement } \\
\text { en transactiekosten }\end{array}$ \\
\hline 2014 & Reynaers & $\begin{array}{l}\text { Vrije Universiteit } \\
\text { Amsterdam }\end{array}$ & $\begin{array}{l}\text { De waarborging van publieke waarden in } \\
\text { publiek-private samenwerking }\end{array}$ \\
\hline 2014 & Willems & $\begin{array}{l}\text { Universiteit Ant- } \\
\text { werpen }\end{array}$ & $\begin{array}{l}\text { Democratische verantwoording in publiek-pri- } \\
\text { vate samenwerking }\end{array}$ \\
\hline 2015 & Aerts & $\begin{array}{l}\text { Vrije Universiteit } \\
\text { Brussel }\end{array}$ & $\begin{array}{l}\text { Kennisoverdracht en -management in publiek- } \\
\text { private samenwerking }\end{array}$ \\
\hline 2015 & De Clerck & $\begin{array}{l}\text { Katholieke Uni- } \\
\text { versiteit Leuven }\end{array}$ & $\begin{array}{l}\text { Aanbesteding van publiek-private samenwer- } \\
\text { kingsprojecten }\end{array}$ \\
\hline 2015 & Leendertse & $\begin{array}{l}\text { Rijksuniversiteit } \\
\text { Groningen }\end{array}$ & $\begin{array}{l}\text { Marktbetrokkenheid in het beheer en de ont- } \\
\text { wikkeling van publieke infrastructuurnetwer- } \\
\text { ken }\end{array}$ \\
\hline 2015 & $\begin{array}{l}\text { Van den } \\
\text { Hurk }\end{array}$ & $\begin{array}{l}\text { Universiteit Ant- } \\
\text { werpen }\end{array}$ & $\begin{array}{l}\text { Standaardisatie van publiek-private samenwer- } \\
\text { kingscontracten }\end{array}$ \\
\hline 2015 & Verweij & $\begin{array}{l}\text { Erasmus Universi- } \\
\text { teit Rotterdam }\end{array}$ & $\begin{array}{l}\text { Management en publiek-private samenwerking } \\
\text { in projectimplementatie }\end{array}$ \\
\hline
\end{tabular}

ben beziggehouden met PPS en die zich ook als zodanig gepositioneerd hebben. Daarbij viel op dat er vooral vanaf 2012 een sterke toename van proefschriften was. Het zoekproces resulteerde in de selectie van veertien proefschriften voor de review (zie tabel 1). Voor elk van de proefschriften hebben wij aan de hand van een vooraf opgesteld protocol - met daarin meerdere aspecten zoals onderzoeksaanleiding, financiering, onderzoeksvragen, onderzoeksmethoden en de voornaamste bevindingen - een samenvatting gemaakt van maximaal vier pagina's. Deze samenvattingen zijn in meerdere rondes besproken en systematisch vergeleken op de verschillende aspecten, resulterend in een uitgebreide overzichtstabel. In wat volgt, presenteren wij onze belangrijkste en opvallendste observaties. 


\section{Een golf van PPS-proefschriften}

De dissertaties geven uiteenlopende redenen voor het belang van onderzoek naar PPS. Veel studies willen bijdragen aan de verbetering van de totstandkoming en werking van bestaande en nieuwe vormen van PPS (bijvoorbeeld Aerts; De Clerck; Eversdijk; Hoezen; Lousberg; Verhees; Verweij). Andere proefschriften willen aandacht schenken aan de problematische kanten van PPS, zoals het in het gedrang komen van legitimiteit en andere publieke waarden (Reynaers; Sanders; Willems). Toch verklaren deze redenen niet waarom er juist in de periode 2012-2015 zoveel proefschriften over PPS zijn verschenen in Nederland en Vlaanderen. Wij zien twee ontwikkelingen als mogelijke verklaringen: (a) de toenemende toepassing van PPS bij infrastructuurprojecten in de periode vanaf 2000, en hiermee samenhangend, (b) de groeiende interesse vanuit de praktijk naar de effecten van PPS. Met name het aantal DBFM-projecten heeft een vlucht genomen in het afgelopen decennium. In Nederland zijn drie golven van PPS-activiteiten te onderscheiden (zie ook Eversdijk \& Korsten, 2015; Klijn, 2009). Aan het eind van de jaren tachtig waren er op rijksniveau de eerste ervaringen met PPS. Na een valse start met de eerste PPS-tunnels werd rond 1998 door het tweede paarse kabinet vanwege budgettaire overwegingen PPS opnieuw omarmd. Een kenniscentrum bij het ministerie van Financiën promootte deze organisatievorm en liet zich daarbij inspireren door DBFM-contracten zoals die in het Verenigd Koninkrijk vorm hadden gekregen. Desondanks kwamen er maar mondjesmaat PPS-contracten tot stand. Dit veranderde pas toen Rijkswaterstaat rond 2006 PPS als default optie adopteerde, en ook de Rijksgebouwendienst en de ministeries van Defensie en Veiligheid en Justitie aanhaakten. Naast budgettaire redenen lagen daar vooral verwachtingen aan ten grondslag over efficiëntievoordelen en voordelen van risico-overdracht naar de private sector. Dit vormde de start voor een derde golf PPS-initiatieven, waarbij een reeks $\mathrm{DBFM}(\mathrm{O})$-projecten in uitvoering werd gebracht. De Vlaamse PPS-projecten zijn veelal wat later gestart dan de Nederlandse. Enkele PPS-projecten in Vlaanderen dateren van eind jaren negentig en begin 2000, maar de meeste en grootste projecten komen voort uit meerdere grootschalige DBFMinvesteringsprogramma's die in de periode vanaf 2004 zijn geïnitieerd door de Vlaamse overheid. Met deze PPS-programma's werd beoogd een zogenoemde inhaalbeweging te maken in het structurele gebrek aan investeringen op het gebied van onder andere wegen, scholen en sportaccommodaties. Kenmerkend aan deze programma's is dat de hoofdzakelijke, en soms enige, motivatie om voor PPS te kiezen was om de investeringen buiten de begroting te kunnen houden. Met een DBFM-constructie is het immers onder bepaalde voorwaarden toegestaan om de investeringskosten te spreiden over de looptijd van het contract. Op deze manier kon België dus op grote schaal investeren en tegelijkertijd blijven voldoen aan de Europese regels omtrent het maximale begrotingstekort (Van Gestel, Willems, Verhoest, Voets, \& Van Garsse, 2014; Verhoest, Van Garsse, Van den Hurk, \& Willems, 2016). Recentelijk zijn hierover spanningen ontstaan omdat in sommige van deze DBFM-projecten overheidsgaranties zijn afgegeven en Eurostat daarom eist dat die projecten terug op de begroting worden geplaatst. 
De golf van proefschriften tussen 2012 en 2015 is volgens ons niet zozeer te verklaren door de voortgang van het wetenschappelijke debat of een hype in de bestuurskundige gemeenschap, maar valt samen met de toename van het aantal DBFM-projecten in zowel Nederland als Vlaanderen. Dit brengt een evaluatievraag met zich mee, wat wordt weerspiegeld in de financiering van promovendi. Hoewel een deel van de proefschriften gefinancierd is vanuit puur wetenschappelijke fondsen (De Clerck; Reynaers; Verweij; Willems), zijn er opvallend veel gefinancierd vanuit de praktijk - ofwel in financiële middelen ofwel in betaalde onderzoekstijd die door de werkgevers van de promovendi werd vrijgemaakt (Aerts; De Schepper; Eversdijk; Leendertse; Lenferink; Verhees). In Nederland betreft het hier vooral (publiek) geld en tijd van Rijkswaterstaat (Eversdijk; Leendertse; Lenferink); in Vlaanderen gaat het om een door private partijen als Deloitte en Grontmij gefinancierde PPS-leerstoel aan de Vrije Universiteit Brussel (Aerts; De Schepper).

\section{Hoe wordt PPS benaderd?}

Een groot deel van de proefschriften definieert PPS als 'lange termijn infrastructuurcontracten' en is daarmee hoofdzakelijk geïnteresseerd in $\operatorname{DBFM}(\mathrm{O})$-projecten (Aerts; De Clerck; De Schepper; Reynaers; Van den Hurk; Willems). In andere onderzochte proefschriften worden ruimere definities gehanteerd. In vier proefschriften worden naast lange termijn PPS-contracten ook korter durende Design-Build (DB) infrastructuurprojecten onderzocht (De Schepper; Hoezen; Lenferink; Verweij) en in drie proefschriften worden ook allianties bekeken (Eversdijk; Verhees; Verweij). De meeste proefschriften definiëren PPS op projectniveau, waarbij Leendertse hierop de opvallendste uitzondering is. Van de veertien proefschriften onderzocht Leendertse publiek-private samenwerking het meest expliciet op systeemniveau, door te kijken naar publiek-private interactie in het beheer van infrastructuurnetwerken in de Grond-, Weg- en Waterbouwsector (GWW-sector). Wat betreft de onderzochte sectoren in de proefschriften, is de transportinfrastructuur dominant. De meeste proefschriften richten zich op de (spoor)wegensector. Sommige proefschriften onderzochten ook 'sociale infrastructuur' (Grimsey \& Lewis, 2004, p. 21; Weihe, 2008, p. 434), zoals scholen, detentiecentra, waterzuiveringsinstallaties en sportfaciliteiten (Reynaers; Van den Hurk; Verhees; Willems), (integrale) gebiedsontwikkeling (Eversdijk; Lousberg; Verhees) en de energiesector (Sanders).

\section{De belangrijkste verschillen}

\section{Projectfasen}

Een in het oog springend verschil tussen de proefschriften betreft de fase van de publiek-private samenwerking die wordt onderzocht. Bijna alle proefschriften focussen zich op de fasen voorafgaand aan de implementatie, dus voordat er een PPS-contract is getekend dat de start van de implementatie markeert. Zes proefschriften onderzoeken de planfase voor de aanbesteding (Eversdijk; Lenferink; 
Lousberg; Reynaers; Verhees; Willems). Een tweede groep van dissertaties richt zich primair op het aanbestedingsproces en de contractering (De Clerck; De Schepper; Hoezen; Van den Hurk). Lenferink en Verhees onderzoeken zowel de planfase als het aanbestedingsproces en de contractering. Alleen Verweij onderzoekt de implementatiefase, hoewel Hoezen ook naar de doorwerking van de contractering in deze fase kijkt. Naast het nagenoeg ontbreken van onderzoek naar de latere PPS-fasen valt dus op te merken dat slechts enkele proefschriften meerdere fasen en de samenhang daartussen analyseren.

\section{Thematische invalshoeken}

Wat betreft het onderwerp, richt het merendeel van de proefschriften zich op de effectiviteitsvraag: welke factoren zijn van invloed op het succes van PPS? Daarbij worden verschillende onderwerpen gekozen. Lenferink en Hoezen onderzoeken hoe de concurrentiegerichte dialoog tijdens de aanbesteding het verloop van projecten beïnvloedt; Verweij richt zich op het effectief management van de implementatie van PPS-projecten; Verhees zoekt naar aanbevelingen om de planning en aansturing van PPS-praktijken te verbeteren; Lousberg bestudeert het succes van interventies bij disfunctionele conflicten; Aerts is geïnteresseerd in de rol van knowledge transfer; en Leendertse bestudeert ten slotte niet de effectiviteit van individuele projecten of programma's, maar hoe transacties en contracten de duurzame marktwerking van de GWW-sector als geheel beïnvloeden.

Een tweede thematische invalshoek betreft de transactiekosten bij aanbestedingsprocedures, die centraal staan in de proefschriften van De Clerck, De Schepper en Van den Hurk. Deze invalshoek staat overigens niet los van het effectiviteitsvraagstuk, want hoge transactiekosten staan de realisatie van PPS-ambities in de weg (Lenferink).

Een derde thematische invalshoek zien we in de proefschriften van Reynaers, Sanders en Willems. Zij nemen afscheid van het dominante effectiviteitsperspectief door zich respectievelijk te richten op vraagstukken van publieke waarden, legitimiteit en verantwoording (zie tabel 1).

Het proefschrift van Eversdijk is een uitbijter omdat het zich richt op de politiekbestuurlijke besluitvorming over PPS in de periode 1986-2011. Het biedt een rijk overzicht van de overwegingen en factoren die in de besluitvorming over PPS een rol hebben gespeeld en daarmee in het verschijnsel PPS zelf.

Sommige proefschriften besteden aandacht aan de rol van stakeholders, zij het terloops of als een van de deelvragen. Dat doen bijvoorbeeld De Schepper en Verweij, waarbij zij beiden ingaan op de vraag wie verantwoordelijk is voor het stakeholdermanagement en met welk effect. Het thema innovatie wordt slechts terloops meegenomen (bijvoorbeeld door Aerts) en dat kan opvallend worden genoemd gegeven de ambities van PPS om innovaties te realiseren en de veelvuldige framing van PPS als innovatief sturingsmodel.

Naast thematische invalshoeken kunnen de proefschriften ook worden onderscheiden naar het perspectief dat ze kiezen: zijn ze geschreven vanuit het perspectief van de overheid of vanuit dat van de private sector? In de proefschriften domineert het publieke perspectief. Alleen de studies die zich om transactiekosten bekommeren, zoeken (ook) antwoorden op vragen van private partijen; het 
proefschrift van De Schepper onderzoekt de determinanten van transitiekosten en De Clerck analyseert met computersimulaties de concurrentiestrijd tussen private partijen. Opvallend, tot slot, is dat waar de praktijk kampt met het onvermogen van publieke en private partijen om elkaar te vinden, slechts enkele proefschriften een louter publiek of privaat perspectief overstijgen. Hoezen en Lousberg zijn hier de welkome uitzonderingen.

\section{Theoretische en disciplinaire invalshoeken}

De meeste proefschriften hanteren inzichten uit de planologie, de bestuurskunde (governance, besluitvorming, procesmanagement) en de vakliteratuur over projectmanagement en publiek-private samenwerking. Lousberg laat zich inspireren door theorieën over conflictmanagement en onderhandelingen, die nauw aan de eerdergenoemde literatuur verwant zijn. De proefschriften van Eversdijk en Willems hebben een aan de bestuurskunde verwant politicologisch accent. Op basis van een literatuuroverzicht komen de meeste proefschriften tot een conceptueel kader, soms uitmondend in een uitgebreide set van proposities of hypothesen (Eversdijk; Leendertse), zonder dat daarbij overigens sprake is van het gebruik van een samenhangende theorie.

Een aantal proefschriften, voornamelijk de Vlaamse, heeft een meer economische oriëntatie, waarbij specifiekere theorieën zoals speltheorie, principaal-agenttheorie en transactiekostentheorie worden gehanteerd (De Clerck; De Schepper; Van den Hurk). Aerts verrijkt het theoretisch palet met literatuur over strategisch management, knowledge transfer en stakeholdermanagement. Ook De Schepper laat zich door stakeholdertheorie inspireren. Voor zover er sprake is van een bedrijfskundig-economische insteek, is die dus te vinden in de Vlaamse dissertaties.

Een juridische insteek ontbreekt opvallend genoeg, waarbij het proefschrift van Sanders de uitzondering is. Ook een discipline als (sociale) psychologie is nagenoeg afwezig, hoewel percepties en relaties in meerdere proefschriften een belangrijke rol spelen. De voornaamste theoretische vernieuwing in de proefschriften lijkt te worden gevonden in het gebruik van systeem- en complexiteitstheorie (Leendertse; Verhees; Verweij). Zo conceptualiseert en analyseert Verhees PPS-projecten als complexe adaptieve systemen en werkt hij op basis daarvan het idee van adaptieve planning uit. Leendertse beschouwt de GWW-sector als complex adaptief systeem en (PPS-)projecten als transacties (en instrumenten) met effecten op de kwaliteit van het netwerk en het netwerkbeheer als geheel.

Al met al valt op dat de auteurs wat betreft theorie vooral in de bekende planologische en bestuurskundige vijver vissen, en dat alleen een enkeling de hengel elders uitgooit.

\section{Methoden van onderzoek}

De overgrote meerderheid van de proefschriften betreft kwalitatief onderzoek en dan vooral casusonderzoek. Er zijn vier uitzonderingen. De Schepper doet een statistische analyse op basis van een survey naar 172 infrastructuurprojecten, Aerts analyseert een enquête verstuurd naar 400 respondenten, Lousberg hield experimenten waarvan de resultaten statistisch zijn geanalyseerd, en De Clerck 
voert (computer)simulaties uit met behulp van economische modellen. In de eerste drie van deze vier studies werden kwantitatieve methoden gecombineerd met kwalitatief casusonderzoek.

De PPS-proefschriften met casusstudies analyseren een beperkt aantal casus van een tot zes (Aerts; De Schepper; Eversdijk; Leendertse; Lenferink; Reynaers; Sanders; Van den Hurk; Verhees; Willems). Sommige studies onderzoeken er meer: Lousberg analyseert tien ruimtelijke ontwikkelingsprojecten, Hoezen zestien concurrentiegerichte dialogen en Verweij 27 transportinfrastructuurprojecten, waarbij hij gebruikmaakt van Qualitative Comparative Analysis als methodiek. Vanwege de lage casusaantallen, en omdat de casusselectie in de proefschriften niet altijd is ingegeven door bewuste theoretische overwegingen, roept het overwicht van casusonderzoek vragen op over de (statistische) generaliseerbaarheid van de onderzoeksresultaten.

\section{De belangrijkste en meest opvallende bevindingen}

Wat zijn nu de bevindingen van de proefschriften en welke nieuwe inzichten bieden ze ons over het verschijnsel publiek-private samenwerking? Deze vraag beantwoorden wij aan de hand van de drie eerder onderscheiden thematische invalshoeken.

\section{Effectiviteit}

Een bevinding die uit diverse proefschriften naar voren komt, is dat de effectiviteit van PPS-arrangementen door de context kan worden belemmerd. Zo concluderen Lenferink en Hoezen dat de concurrentiegerichte dialoog de verwachtingen vaak niet waarmaakt. Lenferink voegt daaraan toe dat hetzelfde geldt voor marktverkenningen, parallellisatie van procedures en levenscyclusintegratie. Verweij stelt verder dat de keuze voor een DBFM-contract een externe oriëntatie van het projectmanagement - nodig om goed in te kunnen spelen op stakeholdercomplexiteit in de context van projecten - kan belemmeren. Ook Verhees voert ongunstige systeemcondities aan als oorzaak voor het uitblijven van succes. Lousberg laat expliciet zien dat de context niet alleen uit harde institutionele factoren bestaat, maar juist ook uit zachte culturele factoren zoals het samenwerkingsklimaat. Deze bevinding sluit aan bij het in de theorie vaak benadrukte belang van vertrouwen (Hodge, Greve, \& Boardman, 2010). Deze eenstemmigheid in de bevindingen lijkt te bevestigen dat PPS, en meer precies DBFM-contracten en het daaraan verwante instrumentarium, als Angelsaksische fremdkörper in een specifieke institutionele omgeving zijn geplaatst waarin ze niet zonder meer passen. Verdere inspanningen zijn nodig om deze institutionele arrangementen succesvol te laten zijn (De Jong, 1999).

Het onderzoek van Eversdijk toont de mechanismen waarmee deze fremdkörper in Nederland geïmplanteerd werden: het politieke enthousiasme stuitte lange tijd op ambtelijk verzet, en pas toen de ambtelijke top bij Rijkswaterstaat in 2006 'om' was, was de weg vrij voor deze nieuwe werkwijze (die van PPS) bij grote rijksprojecten. Publieke controlezucht resulteerde in een voorkeur voor DBFM waarbij 
alternatieve vormen van PPS niet eens overwogen werden. Het proefschrift van Leendertse geeft aan deze bevindingen een extra dimensie door strategieën van publieke en private netbeheerders te vergelijken. Waar de publieke netwerkbeheerders creativiteit en meerwaarde zoeken in projecten, concessies en financiële incentives - die losgekoppeld zijn van het netwerkbeheer als geheel - zoeken private netwerkbeheerders het veeleer in duurzame service-allianties, waarin ook continuïteit en klantnabijheid (en dus in-depth kennis en betrokkenheid) van waarde worden geacht. Daarmee gunt Leendertse ons een blik over de schutting. Hij laat een alternatief zien voor het programma dat het Rijk voor ogen heeft. Dat programma bestaat uit het uitrollen van de DBFM-praktijk over heel Nederland, in de toekomst ook door lagere overheden (provincies, gemeenten, waterschappen) (vgl. Eversdijk \& Korsten, 2015).

De bevindingen ten aanzien van de zachte kant van de governance van PPS hebben ook betrekking op sturing en management. De bevindingen van Lenferink lijken in te houden dat deze het afleggen tegen, of althans beknot worden door, de harde institutionele context die bestaat uit juridische, financieel-economische, technisch-inhoudelijke en organisatorische randvoorwaarden. Maar wellicht is de les juist dat sturing en management met deze randvoorwaarden moeten zien om te gaan, om zo de ambities van PPS te benaderen. Ook Verhees ziet een te strikte contracthandhaving als een probleem, terwijl bij de door hem voorgestelde metaplanning de systeemcondities voor succes kunnen ontstaan. Niet alleen bevestigt Verhees daarmee het belang van management, maar hij laat ook nog iets anders zien. Zijn idee van metaplanning en het bijbehorende adaptieve management lijkt sterk op dat van 'sturen op afstand' en 'functioneel specificeren'. Het zijn ideeën die naadloos in de New Public Management-traditie passen, waar ook de oorspronkelijke filosofie achter DBFM-contracten vandaan komt. Met andere woorden, de bevindingen uit deze proefschriften impliceren geen absolute verwerping van de beleidstheorie achter PPS, noch de unanieme bevestiging van alternatieve, governance-achtige ideeën waarin samenwerking, openheid en vertrouwen ongeconditioneerd als succesformules worden voorgesteld (vgl. Van Ham \& Koppenjan, 2002).

\section{Transactiekosten bij aanbesteding}

De analyse van De Schepper laat zien dat transactiekosten in de aanbestedingsfase bij PPS hoger zijn dan bij traditionele aanbestedingsmethoden. De private partijen hebben bij PPS significant hogere biedingskosten en meer onzekerheid, zeker bij relatief kleinere projecten. Stakeholdermanagement is volgens De Schepper complexer bij PPS, maar wel zeer belangrijk. De computersimulaties van De Clerck bevestigen dat PPS tot hogere transactiekosten leidt in vergelijking met traditionele werkwijzen. Als mogelijke oplossing voor hoge transactiekosten wordt vaak standaardisatie van contracten aangedragen. Van den Hurk stelt echter vast dat standaardcontracten geen garantie bieden op een soepel procesverloop met lagere transactiekosten. Zijn bevindingen sluiten nauw aan bij het hiervoor genoemde belang van de context: elk project heeft zijn specifieke kenmerken en eisen. 


\section{Legitimiteit, accountability en publieke waarden}

Een belangrijke verdienste van het drietal proefschriften dat zich op legitimiteit, verantwoording en publieke waarden richt, is de ontwikkeling van concepten om deze vraagstukken onderzoekbaar te maken. Toekomstig onderzoek kan hierop voortbouwen en verdere consistentie en precisering aanbrengen. De meest interessante bevinding is wellicht dat zowel Reynaers als Willems vaststelt dat PPSprojecten uiteenlopend presteren als het gaat om accountability en het bewaken van publieke waarden. Dat is opmerkelijk, want in de dominante beeldvorming leidt PPS tot depolitisering en tot het domineren van private waarden ten koste van accountability, democratisch gehalte en overige publieke waarden (vgl. Hodge et al., 2010; Van Ham \& Koppenjan, 2002). De proefschriften tonen aan dat PPS in dit opzicht volop potentie heeft: publieke, private en maatschappelijke controlemechanismen kunnen elkaar aanvullen. Dit past ook bij Sanders' bevinding dat PPS vaak gehanteerd wordt als 'reparatiestrategie' voor te veel overheid, markt of netwerkbestuur. Tegelijkertijd constateren de proefschriften dat de verschillende prestaties van de projecten worden verklaard door de inzet van politici, bestuurders, ambtenaren en stakeholders - door of en hoe betrokkenen erin slagen de potenties van PPS te benutten.

\section{Welke aanbevelingen worden gedaan?}

In alle dissertaties worden wel enkele aanbevelingen gedaan, maar de verschillen zijn opvallend. Het proefschrift van Reynaers heeft bijvoorbeeld een zeer hoge theoretische relevantie en gaat minder in op praktische aanbevelingen, terwijl bij Lenferink precies het omgekeerde het geval is: weinig theorie maar veel praktische adviezen. Ook het werk van De Clerck bevat veel praktische adviezen: de computersimulaties die hij heeft uitgevoerd, zijn rechtstreeks vertaald in concrete aanbevelingen over een programmatische PPS-aanpak, over hoe de aanbesteding ingericht zou moeten worden om transactiekosten te beperken (namelijk: weinig kandidaten in de laatste gunningsfase en de toepassing van biedingsvergoedingen), en voorziet bovendien in concrete adviezen aan marktpartijen. Leendertse heeft een apart hoofdstuk gewijd aan concrete verbetervoorstellen voor de praktijk, waarin hij vier opties beschrijft om netwerkbeheer en de markt te beïnvloeden.

Het is interessant dat in tal van de proefschriften de auteurs zich hebben gezet aan het ontwikkelen van afwegingskaders die de rationaliteit van de besluitvorming over PPS moeten bevorderen: De Schepper heeft een hoofdstuk gewijd aan het maken van een ex-ante evaluatieraamwerk voor het beoordelen van het potentieel succes van PPS; Aerts heeft een conceptuele effectiveness benchmark rondom inter-organizational knowledge transfer gemaakt, en Verhees heeft een kader met acht sturingsaspecten rondom metaplanning ontworpen. De vraag is of deze kaders stand houden in de dynamische en politieke context waarin ze hun werk moeten doen. Ook het generieke karakter van deze afwegingskaders roept vragen op. Eversdijk, Lenferink en Verweij benadrukken immers dat project- en 
context-specifieke motieven op de voorgrond moeten staan in de keuze voor PPS en in de inrichting van de specifieke (aanbestedings)processen.

Een andere interessante observatie is dat in veel bestuurskundige proefschriften de aanbevelingen proces-georiënteerd zijn. Lousberg benadrukt bijvoorbeeld dat partijen elkaar moeten leren kennen en persoonlijk contact moeten hebben. Hoezen adviseert meer openheid tussen opdrachtgever en private aanbieders. Met betrekking tot stakeholderparticipatie constateert De Schepper dat dit in de vroege fase de legitimiteit van PPS-projecten vergroot. Verweij suggereert dat stakeholdermanagement tijdens de uitvoering van contracten soms beter in handen van publieke partijen kan worden gelegd. Tot slot zijn Leendertse, Verhees en Verweij kritisch op de principaal-agentachtige relaties die in $\operatorname{DBFM}(\mathrm{O})$-projecten ontstaan en pleiten zij voor andere, meer alliantieachtige contractvormen die volgens hen meer kansen bieden voor echte samenwerking en partnerschap.

De aanbevelingen in de proefschriften rondom legitimiteit, die van Reynaers, Sanders en Willems, zijn vrij abstract van aard en daardoor wellicht minder direct toepasbaar in de dagelijkse PPS-praktijk. Maar net als Eversdijk benadrukken zij dat PPS en $\operatorname{DBFM}(\mathrm{O})$ niet een vanzelfsprekende keuze moet zijn. Zij pleiten voor een intensivering van het politieke en democratische debat over de wenselijkheid van PPS.

Aerts, Eversdijk en Van den Hurk benadrukken het belang van leren en het vasthouden van leerervaringen en kennis, onder andere door het institutionaliseren van leervermogen. Van den Hurk adviseert de Vlaamse overheid daarom een langetermijnstrategie op te stellen, een aansturend agentschap op te richten en meer te investeren in opleiding en training van publieke managers die zijn betrokken bij PPS. Dat is een aanbeveling die waarschijnlijk in de Vlaamse context een grotere urgentie heeft dan in de Nederlandse, waar het Rijk steeds sterk richting aan de PPS-praktijk heeft gegeven. Het proefschrift van Eversdijk laat zien dat aan centralisatie ook nadelen kleven: het legt leerervaringen met betrekking tot $\operatorname{DBFM}(\mathrm{O})$ vast, ten koste van alternatieve ontwikkelingen.

\section{Conclusie}

Deze review van Nederlandse en Vlaamse proefschriften laat zien dat de praktijk van PPS, en meer specifiek die van de lange termijn $\operatorname{DFBM}(\mathrm{O})$-contracten, niet alleen een golf van PPS-projecten kent, maar ook een stroom van onderzoeksprojecten op gang heeft gebracht. Dat onderzoek biedt een rijke bron aan empirische informatie over deze praktijk en draagt in belangrijke mate bij aan onze kennis van het verschijnsel PPS in Nederland en Vlaanderen. Behalve dat de proefschriften tal van specifieke noties opleveren, convergeren hun bevindingen op een aantal punten.

Het belangrijkste gemeenschappelijke inzicht is misschien wel de vaststelling dat PPS-projecten niet automatisch de PPS-beloften waarmaken, maar dat er contextuele beperkingen zijn. Deze beperkingen zijn echter niet onoverkomelijk: door de inzet van betrokkenen kunnen zij worden overwonnen. Eenzelfde observatie wordt gedaan ten aanzien van de gevreesde nadelen van PPS, de risico's ten aan- 
zien van legitimiteit, democratisch gehalte en publieke waarden. Deze zijn niet onvermijdelijk, maar er zijn wel bewuste inspanningen nodig om deze valkuilen te ontlopen. Dit zijn belangrijke inzichten, die zowel fanatieke aanhangers van PPS als hun critici ongelijk geven. PPS is geen wondermiddel, noch een recipe for disaster (zie bijv. ook Verhees \& Verweij, 2016). Een nuchtere, pragmatische houding lijkt op zijn plaats: of en hoe PPS werkt, hangt in sterke mate af van hoe betrokkenen ermee omgaan. Overigens betreft dit een meer generiek inzicht over de relatie tussen structuur en agency, dat niet alleen op PPS-projecten van toepassing is. Structuren geven mogelijkheden en beperkingen, maar wat er uiteindelijk wordt gerealiseerd hangt af van agency (Lowndes \& Roberts, 2013). De proefschriften leren dat voor PPS geldt dat standaardisatie en richtinggevende functionele kaders van belang zijn om transactiekosten te reduceren en dat kennisoverdracht en leren nodig zijn om naast effectiviteit, ook legitimiteit, democratische kwaliteit en publieke waarden te beschermen. Maar voornamelijk komt uit de proefschriften het belang naar voren van de zachte aspecten van samenwerking: het belang van gedrag, de kwaliteit van (duurzame) relaties, van in-depth kennis en klantbetrokkenheid, en van procesgericht (contract)management waarmee ruimte wordt geboden aan flexibiliteit, creativiteit, zelfsturing en gedeelde betekenisverlening. Een aantal proefschriften is daarbij behoorlijk kritisch over de dominantie van $\operatorname{DBFM}(\mathrm{O})$-contracten, die het kat-en-muisspel dat principaalagentrelaties kenmerkt lijken uit te lokken. Sommigen pleiten voor alliantieachtige samenwerkingsvormen, die meer ruimte lijken te bieden voor echte samenwerking.

Uit onze review van de veertien proefschriften blijkt voorts dat zij ons slechts in beperkte mate een blik over de schutting gunnen, zowel in praktisch, thematisch, theoretisch als methodologisch opzicht: ze blijven merendeels dicht bij de bestaande praktijk, de vertrouwde afbakeningen, de gebruikelijke onderwerpen, de bekende theorieën en de geijkte onderzoeksmethoden.

Omdat de proefschriften de praktijk van PPS volgen, richten ze zich vooral op de eerste projectfasen, waaronder die van aanbesteding. Er is nog weinig kennis over de onderhouds- en exploitatiefasen, waarin moet blijken of de beloften van $\operatorname{DBFM}(\mathrm{O})$-contracten worden waargemaakt - terwijl juist nu veel projecten die fasen ingaan. Onderzoek naar die projectfasen zou ook de doorwerking van beslissingen in de vroege fasen op de latere fasen in kaart kunnen brengen. Dat is kennis die nu nog ontbreekt omdat de meeste proefschriften zich op een specifieke fase richten.

Qua thematische invalshoeken zou meer aandacht voor (sociale) innovatie en omgevingsmanagement niet misstaan. Daarnaast zou het mooi zijn als toekomstig onderzoek een specifiek publiek of privaat perspectief zou overstijgen, omdat in de praktijk de pijn juist lijkt te zitten in het onbegrip voor elkaars belangen en opvattingen.

Ook ontbreekt een internationaal vergelijkende invalshoek grotendeels, terwijl de vraag of en wat we van PPS-ervaringen elders zouden kunnen leren voor de hand liggend is. Wat methoden betreft domineert in de huidige proefschriften de casusstudie, waardoor de generaliseerbaarheid van de bevindingen beperkt is. Naast het gebruik van meer vergelijkende onderzoeksmethoden en studies met 
een groter aantal casus, zou een sterkere programmatische afstemming van onderzoek hier ook veel meerwaarde kunnen hebben.

Toekomstig onderzoek zou ook in theoretische zin een grotere variëteit en interdisciplinariteit kunnen gebruiken. De besproken proefschriften doen in theoretisch opzicht aan kluitjesvoetbal door zich vooral door de bekende bestuurskundige, planologische en economisch-institutionele theorievorming te laten leiden. Juridische, financiële en sociaalpsychologische invalshoeken ontbreken. Het zijn nu vooral de complexiteits- en systeemtheoretische noties die verrassende nieuwe invalshoeken bieden, met name waar deze de effecten van keuzen ten aanzien van specifieke contracten en projecten op het niveau van sectoren en netwerken als geheel in kaart brengen. Aandacht voor deze effecten ontbreekt veelal in de overwegingen van beleidsmakers ten aanzien van de vormgeving van specifieke projecten. De vraag is of alternatieve, onverwachte theoretische invalshoeken niet tot heel andere bevindingen zouden hebben geleid.

Doordat de studies de bestaande praktijk evalueren, bieden ze - zoals gezegd maar in beperkte mate een blik over de schutting. $\operatorname{DBFM}(\mathrm{O})$ domineert en alternatieve vormen van publiek-private samenwerking krijgen slechts beperkt aandacht. In de praktijk ontstaan inmiddels nieuwe samenwerkingsvormen rond infrastructurele projecten die door private partijen, maatschappelijke groeperingen of burgers geïnitieerd worden, en die om nieuwe verhoudingen tussen publieke, private én maatschappelijke partijen vragen, waarover nog maar weinig bekend is. Het verbreden van onze review door het includeren van proefschriften die niet geframed zijn als PPS-onderzoek maar die wel nieuwe samenwerkingsvormen onderzoeken, is dan ook een interessante vervolgstap. Niettemin bieden de door ons onderzochte proefschriften inzichten in een aantal generieke mechanismen in publiek-private samenwerking, waar practitioners en onderzoekers die zijn betrokken bij nieuwe projecten, hun voordeel mee kunnen doen.

\section{Literatuur}

Aerts, G. (2015). Essays on public-private mixing: A knowledge transfer perspective. Brussel: Vrije Universiteit Brussel.

Bakker, N. (2015). DBFM-debat: Vier DBFM-onderzoeksopdrachten. Verkeerskunde, 66(1).

De Clerck, D. (2015). Public-private partnership procurement: Game-theoretic studies of the tender process. Leuven: KU Leuven.

De Schepper, S. (2014). Essays on success factors of public-private partnerships in infrastructure. Brussel: Vrije Universiteit Brussel.

Eversdijk, A.W.W. (2013). Kiezen voor publiek-private samenwerking. Maastricht: Universiteit Maastricht.

Eversdijk, A.W.W., \& Korsten, A.F.A. (2015). Motieven en overwegingen achter publiekprivate samenwerking. Beleidsonderzoek Online, DOI: 10.5553/Beleidsonderzoek. 000515.

Grimsey, D., \& Lewis, M.K. (2004). Public private partnerships: The worldwide revolution in infrastructure provision and project finance. Cheltenham: Edward Elgar.

Hodge, G.A., Greve, C., \& Boardman, A.E. (Eds.). (2010). International handbook on publicprivate partnerships. Cheltenham: Edward Elgar. 
Hoezen, M.E.L. (2012). The competitive dialogue procedure: Negotiations and commitment in inter-organisational construction projects. Enschede: University of Twente.

Jong, W.M. de. (1999). Institutional transplantation: How to adopt good transport infrastructure decision-making ideas from other countries? Delft: Delft University of Technology.

Klijn, E.H. (2009). Public-private partnerships in the Netherlands: Policy, projects and lessons. Economic Affairs, 29(1), 26-32.

Klijn, E.H. (2010). Public-private partnerships: Deciphering meaning, message and phenomenon. In G.A. Hodge, C. Greve, \& A.E. Boardman (Eds.), International handbook on public-private partnerships (pp. 68-80). Cheltenham: Edward Elgar.

Koppenjan, J.F.M. (2005). The formation of public-private partnerships: Lessons from nine transport infrastructure projects in the Netherlands. Public Administration, 83(1), 135-157.

Leendertse, W. (2015). Publiek-private interactie in infrastructuurnetwerken: Een zoektocht naar waardevolle marktbetrokkenheid in het beheer en de ontwikkeling van publieke infrastructuurnetwerken. Groningen: Rijksuniversiteit Groningen.

Lenferink, S. (2013). Market involvement throughout the planning lifecycle: Public and private experiences with evolving approaches integrating the road infrastructure planning process. Groningen: University of Groningen.

Linder, S.H. (1999). Coming to terms with the public-private partnership: A grammar of multiple meanings. American Behavioral Scientist, 43(1), 35-51.

Lousberg, L.H.M.J. (2012). Sturen op haalbaarheid en relatie: Interventies om disfunctionele conflicten bij publiek private samenwerking in ruimtelijke ontwikkelingsprojecten te voorkomen. Delft: Technische Universiteit Delft.

Lowndes, V., \& Roberts, M. (2013). Why institutions matter: The new institutionalism in political science. Basingstoke: Palgrave Macmillan.

Loxham, N., \& Ducatteeuw, S. (2015). Samen bouwen aan de toekomst: PPS in Vlaanderen. Brussel: Politeia.

Reynaers, A. (2014). It takes two to tangle: Public-private partnerships and their impact on public values. Amsterdam: VU University Amsterdam.

Rijkswaterstaat. (2011). Samen bouwen aan de toekomst: PPS bij natte en droge infrastructuur. Den Haag: Ministerie van Verkeer en Waterstaat.

Rutte, M., \& Samsom, D. (2012). Bruggen slaan: Regeerakkoord VVD-PvdA. Den Haag.

Sanders, M.P.T. (2013). Publiek-private samenwerking in de Nederlandse energiesector: Vorm en legitimiteit. Enschede: Universiteit Twente.

Schaeffer, P.V., \& Loveridge, S. (2002). Toward an understanding of types of public-private cooperation. Public Performance \& Management Review, 26(2), 169-189.

Van den Hurk, M. (2015). What's the deal? Standardizing contracts for public-private partnerships. Antwerp: University of Antwerp.

Van Gestel, K., Willems, T., Verhoest, K., Voets, J., \& Van Garsse, S. (2014). Public-private partnerships in Flemish schools: A complex governance structure in a complex context. Public Money \& Management, 34(5), 363-370.

Van Ham, H., \& Koppenjan, J.F.M. (Eds.). (2002). Publiek-private samenwerking bij transportinfrastructuur: Wenkend of wijkend perspectief? Utrecht: Lemma.

Verbraeken, H., \& Weissink, A. (2014, 10 juli). Nieuwe Botlek-brug zorgt voor grootste kostenoverschrijding A15-project. Het Financieele Dagblad.

Verhees, F. (2013). Publiek-private samenwerking: Adaptieve planning in theorie en praktijk. Groningen: Rijksuniversiteit Groningen.

Verhees, F., Marrewijk, A. van, Leendertse, W., \& Arts, J. (2015). Publiek en privaat: Een spannende relatie in de bouw- en infraketen. Beleidsonderzoek Online, DOI: 10.5553/ BO/221335502015000020001. 
Verhees, F., \& Verweij, S. (2016). DBFM: Medicijn met bijwerkingen: Gezamenlijk risico's delen en stakeholders managen. ROmagazine, 34(3), 32-34.

Verhoest, K., Van Garsse, S., Van den Hurk, M., \& Willems, T. (2016). Developments of public-private partnership in Belgium. In A. Akintoye, M. Beck, \& M. Kumaraswamy (Eds.), Public-private partnerships: A global review (pp. 45-58). London: Routledge.

Verweij, S. (2015). Once the shovel hits the ground: Evaluating the management of complex implementation processes of public-private partnership infrastructure projects with qualitative comparative analysis. Rotterdam: Erasmus University Rotterdam.

Weihe, G. (2008). Ordering disorder - On the perplexities of the partnership literature. Australian Journal of Public Administration, 67(4), 430-442.

Willems, T. (2014). Lost in diffusion? Democratic accountability in public-private partnerships. Antwerpen: Universiteit Antwerpen. 